\title{
Hodrick-Prescott filtering of Large, emerging Economies and Analysis of Russian GDP Growth
}

\author{
By Olga V. Mezentceva* \\ Ann V. Mezentceva ${ }^{\dagger}$
}

The output gap is one of the main indicators used for economic policy-making in the modern, post-crisis period. Firstly, we calculated the output gap of large developing countries: Russia, India and China. The output gap, in this case, was considered to be an indicator of the efficiency of the use of resources in the economy and used the method of Hodrick-Prescott filtering. Next, we performed an empirical analysis of the impact of a number of macroeconomic factors on economic growth in Russia. After that, using the generalized autoregressive conditional heteroskedasticity model, we identified which variables have a significant impact on the growth of the Gross Domestic Product (GDP) of Russia. Our study showed that Russia, unlike China and India, has a negative output gap. The most significant impact on GDP growth in Russia has an index of Claims on the private sector, indicating that the continued dependence of the Russian economy, business from the global financial markets, and the availability of these markets are important drivers of economic growth.

Keywords: Decoupling hypothesis, Emerging economy, GARCH-model, HodrickPrescott filtering, Output gap.

\section{Introduction}

Today, the global economy is undergoing a series of transitional processes (Bäurle and Burren 2011, Ben et al. 2012, Sujic et al. 2011). One of the hottest topics is the issue of stimulating growth and increasing efficiency in the global economy (Boldrin et al. 2001, Coudert et al. 2011, Lee 1996); much attention has been directed towards the issue of developed and developing countries' economic cycles having a mutual impact on each other (Das 2010, Imbs 2004, Rose and Engle 2002), especially in terms of overcoming gaps in production output. Before the 2009 crisis, at a time when the economies of the AsiaPacific region were developing markedly and the price of raw materials was climbing constantly (Erdorf and Heinrichs 2011, Sharma 2011, Yetman 2011), the decoupling hypothesis (about the economic cycles of developing countries becoming more separated from those of developed countries) became very relevant (Kose et al. 2008). However, since the 2009 crisis, several articles have appeared asserting a decrease or disappearance of the decoupling effect after the crisis (Dimitriou et al. 2013, Wälti 2012), although there are still some noting the effect's presence (Dooley and Hutchison 2009, Gilenko and Fedorova 2014).

${ }^{*}$ Associate Professor, The Ural Federal University, Russia.
${ }^{\dagger}$ Associate Professor, The Ural Federal University, Russia.

https://doi.org/10.30958/ajbe.1-4-2

doi=10.30958/ajbe.1-4-2 
Also relevant are questions concerning the pros and cons of globalization and the development of various unions (Frankel and Rose 1998, McKinnon, 1963, Mundell 1961, Papageorgiou et al. 2010). These are discussed here and also in the literature, opinions diverge. Some researchers note the presence of "spillover effects" resulting from developing countries joining such unions (Das 2010, Dooley and Hutchison 2009), while other researchers have expressed apprehension regarding the positive effects of the unions (Tsheola 2002a, 2002b).

This article continues a series of articles, devoted, to the authors, to stimulate economic growth in large developing countries: Russia, India and China. Synchronization of business cycles and the identification of macroeconomic factors affect their growth. In this article we have tried to identify which of the macroeconomic factors have a greater impact on economic growth. Our task is dictated by the fact that economic growth in large developing countries is of different character and is based on profound differences in the economic structure of these countries (Kizys and Pierdzioch 2010, Schwert 1989, Schwert 1990). Accordingly, our research hypothesis is that the macro-economic factors largely affecting growth may be different. Furthermore, in order to determine where we will have an increased impact on economic growth and where we will have a decreased impact, several universal factors, impacting economic growth in all the large, emerging economies, have been identified.

On the other hand, given the current circumstance of sluggish economic growth in countries with developing economies, decreased prices for raw materials, and developing countries' economic cycles transitioning into a phase of decline, it is important to research more thoroughly the cyclical and the structural components of economic growth in large, emerging countries, especially those where economic growth is profoundly linked with raw materials (Russia), rather than with industrial production (China, India).

Therefore, the second section of this article inspects the connectedness of the GDP and macroeconomic factors of large, emerging countries. The methodological basis of our empirical analysis is based on the Hodrick-Prescott filtering technique and on a model of autoregressive conditionallyheteroskedastic processes, which allow us to reveal any mutual connection between the GDP of large, emerging countries and macroeconomic factors. The third section provides and discusses the statistical results of the research. The fourth section analyzes the results and the contradictions that arose and makes an attempt to explain them.

Despite the fact that the Hodrick-Prescott filtering technique is widely used as a technique for breaking time series into structural and cyclic components and eliminating trends, it is far from being perfect, which serves as a limitation on the current research (Cogley and Nason 1995, Kaiser 1999, King and Rebelo 1993a, King and Rebelo 1993b). 


\section{Methods}

\section{Decoupling Hypothesis}

Before the 2009 crisis, it was possible to observe various symptoms of developing countries' economic cycles becoming disconnected from those of developed countries (decoupling hypothesis). However, today the situation has changed (Chkili and Nguyen 2014). Countries with developed economies have gradually become stronger since the 2009 crisis. The USA and the European Union countries are gradually ending their policy of collective mitigation to stimulate their own productive forces, resulting in economic growth. While this is going on, developing countries are running into the problem of stagnant economic growth and the necessity of adapting to being in the "decrease" phase of the economic cycle. As a result, we are witnessing an outflow of capital and a devaluation of national currency in developing markets, the markets which large, emerging countries are connected with. In these conditions, it is doubtful that we will find evidence in support of the decoupling hypothesis.

Table 1. Macroeconomic Variables

\begin{tabular}{|c|c|}
\hline Name & Variable Definition \\
\hline $\begin{array}{l}\text { Foreign direct } \\
\text { investment, net } \\
\text { inflows (BoP, } \\
\text { current US\$) }\end{array}$ & $\begin{array}{l}\text { Foreign direct investments are the net inflows of investment that } \\
\text { acquire a lasting management interest ( } 10 \% \text { or more of voting stock) in } \\
\text { an enterprise operating in an economy other than that of the investor. } \\
\text { Data are in current US dollars. }\end{array}$ \\
\hline $\begin{array}{l}\text { Export of goods and } \\
\text { services (current } \\
\text { US\$) }\end{array}$ & $\begin{array}{l}\text { Export of goods and services represent the value of all goods and other } \\
\text { market services provided to the rest of the world. Data are in current } \\
\text { US dollars. }\end{array}$ \\
\hline $\begin{array}{l}\text { Gross fixed capital } \\
\text { formation (current } \\
\text { US\$) }\end{array}$ & $\begin{array}{l}\text { Gross fixed capital formation (formerly gross domestic fixed } \\
\text { investment) includes land improvements (fences, ditches, drains, and so } \\
\text { on); plant, machinery, and equipment purchases; and the construction } \\
\text { of roads, railways, and the like, including schools, offices, hospitals, } \\
\text { private residential dwellings, and commercial and industrial buildings. } \\
\text { Data are in current US dollars. }\end{array}$ \\
\hline $\begin{array}{l}\text { Changes in } \\
\text { inventory (current } \\
\text { US\$) }\end{array}$ & $\begin{array}{l}\text { Inventories are stocks of goods held by firms to meet temporary or } \\
\text { unexpected fluctuations in production or sales, and "work in progress". } \\
\text { Data are in current US dollars. }\end{array}$ \\
\hline $\begin{array}{l}\text { Gross capital } \\
\text { formation }(\% \text { of } \\
\text { GDP) }\end{array}$ & $\begin{array}{l}\text { Gross capital formation (formerly gross domestic investment) consists } \\
\text { of outlays on additions to the fixed assets of the economy plus net } \\
\text { changes in the level of inventories. }\end{array}$ \\
\hline $\begin{array}{l}\text { Lending interest rate } \\
(\%)\end{array}$ & $\begin{array}{l}\text { The lending rate is the bank rate that usually meets the short- and } \\
\text { medium-term financing needs of the private sector. }\end{array}$ \\
\hline $\begin{array}{l}\text { Personal } \\
\text { remittances, paid } \\
\text { (current US\$) }\end{array}$ & $\begin{array}{l}\text { Personal remittances comprise personal transfers and compensation of } \\
\text { employees. Personal transfers consist of all current transfers in cash or } \\
\text { in kind made or received by resident households to or from nonresident } \\
\text { households. Data are in current US dollars. }\end{array}$ \\
\hline $\begin{array}{l}\text { Claims on the } \\
\text { private sector } \\
\text { (annual growth as \% } \\
\text { of broad money) }\end{array}$ & $\begin{array}{l}\text { Claims on the private sector include gross credit from the financial } \\
\text { system to individuals, enterprises, nonfinancial public entities not } \\
\text { included under net domestic credit, and financial institutions not } \\
\text { included elsewhere. }\end{array}$ \\
\hline
\end{tabular}

Source: World Bank Open Data 2014. 
Therefore, in order to eliminate the influence of financial markets, inflation, and currency exchange rates on the economic cycle, we chose to use GDP in a constant price as the subject of empirical analysis in our research. Macroeconomic variables are also, in part, based on the economic cycle. This is the most traditional approach, and we also scrutinize a set of interrelated macroeconomic variables (Table 1).

\section{Hodrick - Prescott Filtering}

The Hodrick - Prescott filtering is one of the most popular ways to expand a time series of economic data into a trend and a cycle. This expansion is crucial for us to express the output gap, the difference between the actual and predicted GDP. The existence of an output gap indicates that the economy is functioning at an inefficient level, using its resources either too much or not enough.

By "trend" we mean a certain steady, systematic change over the course of a long period. However, no matter how large the series, one can never be certain that the trend is not just part of a slow oscillation. Having set a trend apart from seasonal oscillating changes, series depict a more or less regular fluctuation. Seasonal effects are easier to discover, set apart, and study. Here, changes that occur are applied to the system by some cyclical mechanism external in its relationship to the basic mechanisms which define the system's behavior.

When determining the trend, we understand that any movement observed over the course of a long enough time will appear to be smoothed-out. This means that, at least locally, the component corresponding to the trend can be expressed by a polynomial of time $\left({ }^{t}\right)$.

So, in our case, GDP is expanded into a trend and deviation from that trend (Hodrick and Prescott 1997, Tsyplakov 2011):

$$
y_{t}=y_{t}^{g}+y_{t}^{e},
$$

where $y_{t}^{g}$ is a trend or structural component of the time series and $y_{t}^{? ?}$ is the cyclical component of the time series.

To get a smoothed-out series, we apply conditions which minimize the cyclical component's deviation:

$$
\sum_{t=0}^{\infty}\left(y_{t}^{c}\right)^{2}+\lambda \sum_{t=0}^{\infty}\left[\left(y_{t+1}^{g}-y_{t}^{g}\right)-\left(y_{t}^{g}-y_{t-1}^{g}\right)\right]^{2} \rightarrow \min
$$

where $\lambda$ is a Lagrange multiplier. For annual data, $\lambda=100$.

Then, after isolating the trend, we inspected the rest of the series using spectral methods of analysis.

Methodology of Empirical Analysis by $\operatorname{GARCH}(1,1)$

Next, we investigated the "GDP growth rates of large, emerging countries" data set as a time series. Based on the GDP time series and the 
macroeconomic variables time series, generalized autoregressive conditional heteroskedastic models were created $(\mathrm{GARCH}(1,1)$. GARCH models have become popular in economic literature since the end of the 1980s (Bollerslev 1986, 1990) and are currently widely used for the empirical evaluation of interrelatedness between economic processes expressed in terms of time series.

The model is as follows. Let there be a regression of time series $y_{t}$ on all other time series, where all of the time series involved fit the conditions of a stationary process:

$$
y_{t}=x_{t}^{2} \beta+u_{t} .
$$

This means that a tendency toward clustering can be observed in the data points of these series with large or small deviations from the average. In other words, periods of stability alternate with periods of agitation.

This clustering is explained by a model in which the variance of error $u_{t}$ is dependent on the instances preceding:

$$
\sigma_{t}^{2}=\alpha_{0}+\alpha_{t} u_{t-1}^{2}+\cdots+\alpha_{p} u_{t-p}^{2}
$$

A more generalized model for aligning the variance of errors was proposed in (Bollerslev 1986):

$$
\sigma_{t}^{2}=\alpha_{0}+\alpha_{t} u_{t-1}^{2}+\cdots+\alpha_{p} u_{t-p}^{2}+\gamma_{1} \sigma_{t-1}^{2}+\cdots+\gamma_{p} \sigma_{t-p}^{2}
$$

Since the initial time series are not stationary, we must use a logarithm on the GDP indices and on the macroeconomic factor indices. Let $X_{t}$ be the difference in the natural logarithms of the indices of GDP and macroeconomic factors:

$$
X_{t}=\ln \frac{G D P_{t}}{G D P_{t-1}}-\ln \frac{F_{t}}{F_{t-1}},
$$

where $G D P_{t}$ is the GDP in constant price of the country at a moment in time t and $F_{t}$ is the macroeconomic factor of the country at a moment in time $\mathrm{t}$.

In this case, the model of aligning the rate of increase in the two indices is:

$$
\begin{aligned}
& \Delta X_{t}=\text { const }+\mu X_{t-1}+\varepsilon_{t}, \\
& \text { where } \Delta X_{t}=X_{t}-X_{t-1} .
\end{aligned}
$$

The value $\mu$ gives evidence for the interconnectedness between the GDP rate and the macroeconomics variable. The variable $\mu$ indicates the level of integration of the two time series. 


\section{Results}

\section{Hodrick - Preskott Filtering}

Having applied the procedure of Hodrick - Preskott filtering we separated the cyclical component of structure for all of the countries under consideration. Thus, our aim was, firstly, to identify the presence of an output gap, and, secondly to trace the dynamics of the gaps in the output (output gap) to identify situations of inefficiency in the economy. The eliminate series, or in other words dynamics of the output gap, as a result of the smoothing time series the GDP of BRICS countries, are presented in Figure 1.

Figure 1. Output Gap of Large, Emerging Countries: India, China, Russia

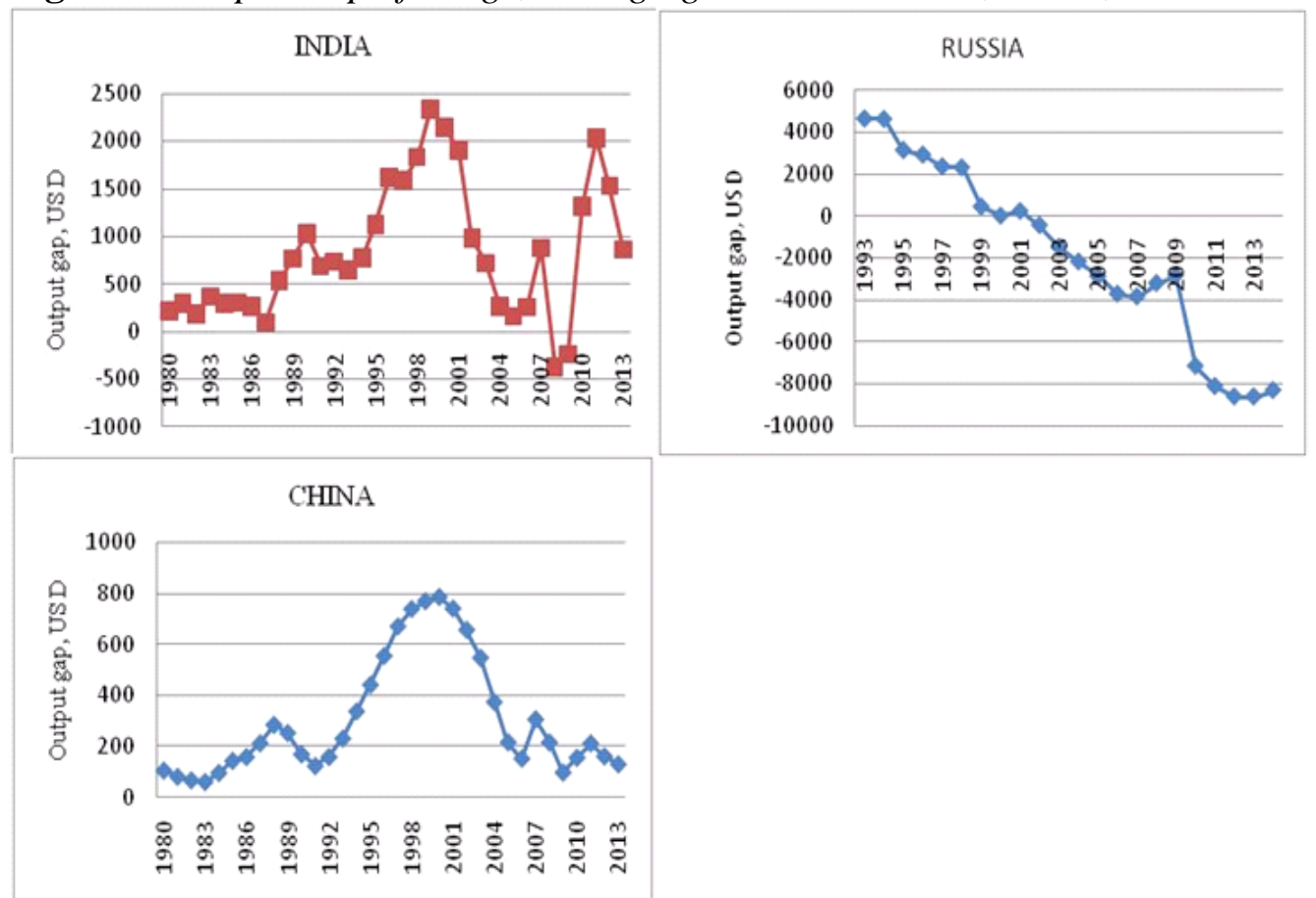

Source: World Economic Outlook, 2013 and Fieldwork Survey Data 2014.

The Figure 1 shows that the gap volumes of manufacture (output gap) for the BRICS countries have fundamentally different characteristics. For Brazil and South Africa there are constant output gap fluctuations. This means their economies function is sometimes excessive and sometimes it demonstrates an insufficient consumption of resources.

India and China are characterized by a period of economic growth with a positive output gap in the period from 1992 to 2005. So, the economies of these countries use their resources too rapidly and, for this reason, are now faced with stagnation of economic growth.

In Russia, the situation is most alarming because the output gap in Russia has had a stable negative value since 2001, which means its economy is 
inefficient and is not using enough available resources, and the global financial crisis of 2009 has only exacerbated this inefficiency.

\section{Macroeconomic Variable Analysis by $\operatorname{GARCH}(1,1)$}

Further, for a deeper study of the dynamics of various causes of economic growth, we tried to analyze the impact of the growth rates of individual macroeconomic indicators by the growth rate of the GDI method of generalized autoregressive conditional heteroskedastic model. The results are shown in Table 2.

Table 2. Macroeconomic Variable Analysis Results

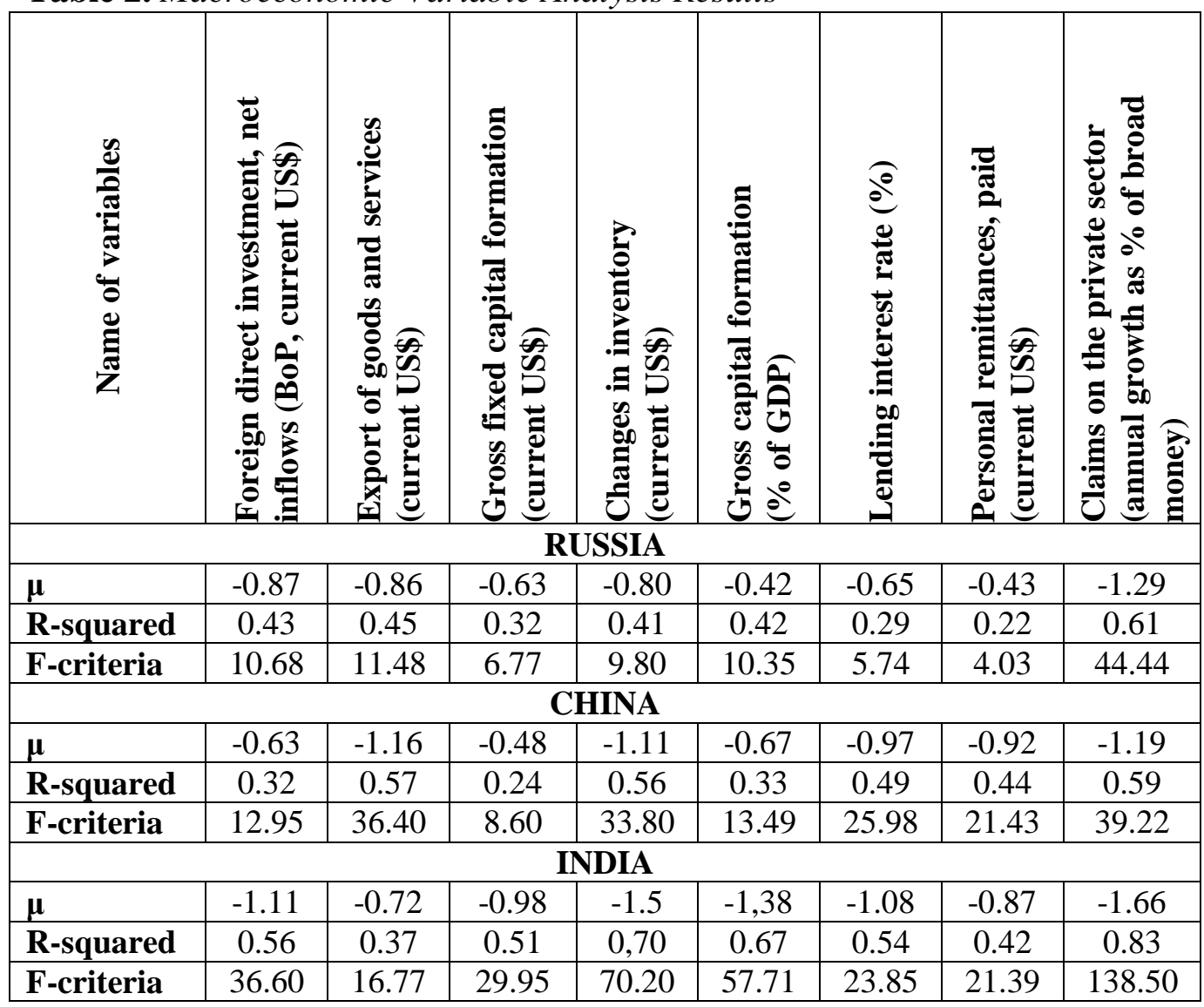

Source: Fieldwork Survey Data 2014.

Table 2 shows that, of all the studied macroeconomic variables, the most influential variable was "Claims on the private sector", both for Russia and for China and India. This indicates a high dependence on large, emerging economies and global financial flows by accessing them. In the meantime, other relevant factors for Russia were not found. While the rate of the GDP growth in China also affects "Export of goods and services" and "Changes in inventory". Therefore, we have empirical evidence that China is an exportoriented country and that the manufacturing sector plays a leading part in the Chinese economy. 
In India, the same variables showed the greatest significance related to the real economy and the redistribution of the physical capital: foreign direct investment, changes in the inventory, gross capital formation. A characteristic feature of all large emerging economies is that the Claims on the private sector variable play the greatest significance in the economic growth of these countries.

\section{Discussion}

Our study has shown that Russia, India and China have fundamentally different dynamics of the output gap. The dynamics of the output gap in China and India are similar, and in Russia the level of GDP turned out to be well below the potential level, indicating an inefficient use of resources in the economy of Russia (Kose et al. 2008). In addition, there are strong differences in the importance of macroeconomic variables. This confirms the idea that large, emerging economies have a different economic structure and each country faces its own challenges and must find its own way of solving problems (Utting 2013). In addition, our study showed that large, emerging economies have a strong dependence on the financial sector of the global economy. It prevents us from supporting the decoupling hypothesis.

Despite this, our research fits in the existing paradigm of research on this topic. Before the financial crisis of 2009, there was an period of fast growth in developing countries' economies, especially Asian ones (Felices and Wieladek 2012, Kawai and Petri 2014, Kose et al. 2008). Most researchers found evidence of the decoupling hypothesis and spillover effects in their research (Das 2010, Dooley and Hutchison 2009, Gilenko and Fedorova 2014). However, the global crisis of 2009 changed the trend (Yeyati and Williams 2012) and research has begun to show more and more evidence of reduction in the decoupling hypothesis and spillover effects since the 2009 crisis.

Our research also indirectly supports the results of other researchers, who have noted a substantial decrease in the decoupling effect after the 2009 crisis (Dimitriou et al. 2013, Wälti 2012).

\section{Research Limitations}

Although the Hodrick-Prescott filtering technique is widely used to conduct the output gap analysis as well as to synchronize business cycles, it has received considerable criticism in research papers:

Firstly, when performing its function of eliminating trends, it is no better than other leveling methods, such as the method of exponential leveling. The method also displays no advantages when it comes to explaining real business cycles (King and Rebelo 1993a, 1993b). 
Secondly, there is proof that during spectral analysis, the Hodrick-Prescott filtering technique can show the presence of cyclical fluctuations, i.e. cyclical components, when in fact there are none (Cogley and Nason 1995).

Moreover, Kaiser (1999) mentions that the Hodrick-Prescott filtering technique does not allow the testing of the remainders of the time cycle for the presence of the cyclical component and white noise.

In extenuation of the results of the research, it can be stated that in earlier research (Mesentceva et al. 2014) we conducted spectral analysis of business cycles of large emerging economies. These results fully corroborate the validity of the findings presented in this paper.

\section{Conclusions}

We have carried out research on the level of efficiency and economic growth of large, emerging economies. In doing so, we used two methods: Hodrick - Prescott filtering and a macroeconomic variable analysis by a generalized autoregressive conditional heteroskedastic model. By using Hodrick - Prescott filtering, we have discovered the varied nature of the output gap dynamics of large, emerging economies, which has allowed us to conclude that that the decoupling hypothesis cannot be supported at this time. Th macroeconomic variable analysis by the generalized autoregressive conditional heteroskedastic model yielded similar results. In the future, we plan to examine the large, emerging countries' cooperation using a broader set of macroeconomic variables.

\section{References}

Bäurle G, Burren D (2011) Business cycle accounting with model consistent expectations. Economics Letters 110(1): 18-19.

Ben Kheder S, Zugravu N (2012) Environmental regulation and French firms location abroad: An economic geography model in an international comparative study. Ecological Economics 77: 48-61.

Boldrin M, Lawrence LJ, Fisher JD (2001) Habit persistence, asset returns, and the business cycle. American Economic Review 91:149-166.

Bollerslev T (1986) Generalized autoregressive conditional heteroskedasticity. Journal of Econometrics 31(3): 307-327.

Bollerslev T (1990) Modeling the coherence in short-run nominal exchange rates: A multivariate generalized arch model. The Review of Economics and Statistics 72(3): 498-505.

Chkili W, Nguyen DK (2014) Exchange rate movements and stock market returns in a regime-switching environment: Evidence for BRICS countries. Research in International Business and Finance 31: 46-56.

Cogley T, Nason ST (1995) Effects of the Hodrick-Prescott filter on trend and difference stationary time series Implications for business cycle research. Journal of Economic Dynamics and Control 19(1-2): 253-278. 
Coudert V, Couharde C, Mignon V (2011) Exchange rate volatility across financial crises. Journal of Banking and Finance 35(11): 3010-3018.

Das DK (2010) Another perspective on globalization. Journal of International Trade Law and Policy 9(1): 46-63.

Dimitriou D, Kenourgios D, Simos T (2013) Global financial crisis and emerging stock market contagion: A multivariate FIAPARCH-DCC approach. International Review of Financial Analysis 30: 46-56.

Dooley M, Hutchison M (2009) Transmission of the US subprime crisis to emerging markets: Evidence on the decoupling-recoupling hypothesis. Journal of International Money and Finance 28(8): 1331-1349.

Erdorf S, Heinrichs N (2011) Co-movement of revenue: structural changes in the business cycle. European Economic Review 1(41): 761-770.

Felices G, Wieladek T (2012). Are emerging market indicators of vulnerability to financial crises decoupling from global factors? Journal of Banking and Finance 36(2): 321-331.

Frankel J, Rose A (1998) The endogeneity of the optimum currency area criteria. The Economic Journal 108: 1009 -1025.

Gilenko E, Fedorova E (2014) Internal and external spillover effects for the BRIC countries: Multivariate GARCH-in-mean approach. Research in International Business and Finance 31: 32-45.

Hodrick R, Prescott EC (1997) Postwar Business Cycles: An Empirical Investigation. Journal of Money, Credit, and Banking 29(1): 1-16.

Imbs J (2004) Trade, finance, specialization, and synchronization. Review of Economics and Statistics 86(3): 723-734.

Kaiser R (1999) Detection and estimation of structural changes and outliers in unobserved components. Computational Statistics 14(4): 533-558.

Kawai M, Petri PA (2014) Asia's role in the global economic architecture, Contemporary Economic Policy 32(1): 230-245.

King RG, Rebelo ST (1993a) Low frequency filtering and real business cycles. Journal of Economic Dynamics and Control 17(1-2): 207-231.

King RG Rebelo ST (1993b) Transitional dynamics and economic growth in the neoclassical model. American Economic Review 83(4): 908-931

Kizys R, Pierdzioch C (2010) The business cycle and the equity risk premium in real time. International Review of Economics and Finance 19: 711-722.

Kose MA, Otrok C, Prasad E (2008) How much decoupling? How much converging? Finance and Development 45(2): 36-40.

Lee K (1996) Long-term output growth as a predictor of stock returns. Applied Financial Economics 16: 421-432.

McKinnon R (1963) Optimum currency areas. American Economic Review 53(4): $717-725$.

Mezentceva OV, Shelomentcev AG, Kuzmin AI, Mezentceva AV (2014) Empirical valuation of economics cycles synchronization in BRICS. Life Science Journal 11(11s): 494-498.

Mundell RA (1961) A theory of optimum currency areas. American Economic Review 51(4): 657-665.

Papageorgiou T, Michaelides PG, Milios JG (2010) Business cycles synchronization and clustering in Europe (1960-2009). Journal of Economics and Business 62: 419-470.

Rose AK, Engel C (2002) Currency unions and international integration. Journal of Money, Credit and Banking 34(4): 1067-1089. 
Schwert GW (1989) Why does stock market volatility change over time? Journal of Finance 44: 1115-1153.

Schwert GW (1990) Stock returns and real activity: A century of evidence Journal of Finance 45: 1237-1257.

Sharma SD (2011) Not an exceptional country: Russia and the global financial crisis of 2008-2009. Mediterranean Quarterly 22(2): 31-44.

Sujic M, Milosev M, Brkanlic S (2011) Global Investments and strategies of recovery from the recession. Procedia - Social and Behavioral Sciences 24: 147-158.

Tsheola J (2002a) South Africa in Gear: "A better life for all" or a zero-sum game of globalization? GeoJournal 57(1-2): 79-92.

Tsheola J (2002b) South Africa's form of globalization: A continental posture paradox for insertion and dependence. Political Geography 21(6): 789-811.

Tsyplakov A (2011) An introduction to state modeling. Quantile 9: 1-24.

Utting P (2013) What is Social and Solidarity Economy and Why Does it Matter? Geneva, United Nations Research Institute on Social Development. Retrieved from http://goo.gl/M3detj. [Accessed: 25 July 2014].

Wälti S (2012) The myth of decoupling. Applied Economics 44(26): 3407-3419.

World Bank Open Data (2014) The World Bank. Retrieved from http://data.world bank.org/. [Accessed: 10 August 2014].

World Economic Outlook (2013) International Monetary Fund. Retrieved from http://goo.gl/8tnIX. [Accessed: 15 January 2014].

Yetman J (2011) Exporting recessions: International links and the business cycle. Economics Letters 110: 12-14.

Yeyati EL, Williams T (2012) Emerging economies in the 2000s: Real decoupling and financial recoupling. Journal of International Money and Finance 31(8): 21022126. 
